\title{
EFEKTIVITAS PENERAPAN APLIKASI SIMBANGDA PADA BAGIAN KEUANGAN KANTOR DPRD PROVINSI SUMATERA BARAT
}

\author{
Nira Elsa Ramadhani \\ Jurusan Administrasi Publik, Fakultas Ilmu Sosial Universitas Negeri Padang \\ Email : nira.elsa02@gmail.com \\ Nora Eka Putri \\ Jurusan Administrasi Publik, Fakultas Ilmu Sosial Universitas Negeri Padang \\ Email: noraekaputri@fis.unp.ac.id
}

\begin{abstract}
At present the use of information technology in government agencies is increasingly being found. One form of utilization of management information systems in government organizations is the Regional Development Information System (SIMBANGDA). SIMBANGDA application is software that is designed to simplify and integrate budget data available in each budget month to report on the development of financial realization and the state of physical realization of work carried out by the Regional Devices Organization (OPD). This research is a qualitative research with descriptive method. The informant of the research was conducted by Purposive Sampling. The technique of data collection is done by observation, interviews and documentation studies. The validity test of the data is done by source triangulation techniques, then the data is reduced and conclusions are drawn from the results of the study.

The results of this study indicate that (1) consists of 3 indicators (a) In achieving the objectives it is still not maximal because there are still errors in the calculation of financial realization in the application. (c) and the adaptation of SIMBANGDA operators is still not maximal because there are still those who do not understand how to use SIMBANGDA Apps (2) the availability of sufficient hardware and software and (3) there are still operator errors in the data entry process.
\end{abstract}

Keywords:Effectiveness, Management Information System, Electronic Government, SIMBANGDA. 


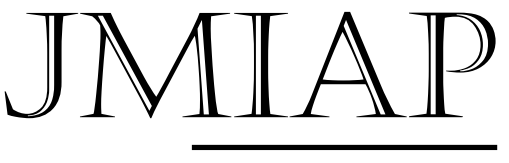

jmiap.ppj.unp.ac.id

\section{Pendahuluan}

Penerapan aplikasi SIMBANGDA pertama kali dibuat berdasarkan Instruksi Presiden Republik Indonesia Nomor 3 Tahun 2003 Tentang Strategi Dan Kebijakan Nasional Pengembangan E-Government, dengan unsur pokok Keterbukaan (transparancy), Peningkatan efisiensi di segala bidang (effieciency). Tanggung jawab yang jelas (responsibility) dan, Kewajaran (fairness). Sistem Informasi Pembangunan Daerah sendiri diatur dalam Undang-Undang Nomor 32 Tahun 2004 tentang Pemerintahan Daerah yang kemudian direvisi menjadi Undang-Undang Nomor 23 Tahun 2014 pada pasal 274 mengamanatkan bahwa perencanaan pembangunan daerah didasarkan pada data-dataserta informasi yang dikelola dalam Sistem Informasi Pembangunan Daerah. Hal ini semakin memperkuat posisi Sistem Informasi Pembangunan Daerah sebagai bahan rujukan dalam proses penyusunan dokumen perencanaan pembangunan daerah. Namun penggunaan aplikasi SIMBANGDA sebagai acuan dalam penyusunan dokumen perencanaan pembangunan daerah difokuskan kepada pemanfaatan informasi yang dihasilkan berdasarkan pengolahan data yang telah diinput oleh pemerintah daerah.

Gambaran umum pemakaian aplikasi SIMBANGDA yang pertama yaitu Bagian/Sub Bagian Program pada masing-masing SKPD sebagai Pemakai (User) yang bertugas memasukkan data kegiatan, anggaran, target realisasi diawal tahun, serta realisasi setiap bulannya baik fisik maupun keuangan. Yang kedua, Pengguna Anggara (PA) pada masing-masing SKPD sebagai Pemakai (User) yang dapat melihat informasi realisasi pelaksanaan kegiatan pada SKPD mereka guna pengendalian kegiatan dilingkungan
SKPD mereka. Yang ketiga Bagian/Sub Bagian pada Biro Administrasi Pembangunan dan Kerjasama Rantau/Bagian Pembangunan pada $\mathrm{Kab} /$ Kota sebagai Pemakai (User) dapat melihat informasi realisasi pelaksanaan kegiatan pada SKPD mereka guna kebutuhan penyiapan bahan rapat monev, pengendalian kegiatan pembangunan, pelaporan dan lain-lain. Yang keempat Pengelola Simbangda (User Admistrator) sebagai Pemakai (User) bertugas melakukan pengaturan terhadap siapa yang berhak mengakses dan sejauh mana haknya dengan memberikan nama user (user name) dan kata kunci masuk (password), serta melakukan pengelolaan dan perawatan.

Kantor Dewan Perwakilan Rakyat Daerah Provinsi Sumatera Barat merupakan salah satu lembaga pemerintahan yang telah menerapkan sistem E-Government salah satunya dengan penerapan aplikasi SIMBANGDA. Operator yang bertugas mengentrikan data ke dalam Aplikasi SIMBANGDA di Kantor DPRD Provinsi Sumatera Barat yaitu pada Bagian Keuangan di Sub Bagian Akuntansi Pelaporan dan Verifikasi, kemudian tiap tanggal 8 setiap bulannya staff yang bertugas mengentrikan data ke Aplikasi tersebut wajib mengirimkannya kepada Biro Kerja Sama Pembangunan dan Rantau selaku organisasi yang bertugas mengelola apliaksi dan menghimpun data keuangan dari setiap SKPD, lalu Biro Kerja Sama Pembangunan dan Rantau akan melakukan evaluasi bersama Gubernur yang dalam kurun waktu 3 bulan sekali, dan hasil evaluasi tersebut akan dimanfaatkan dalam proses pengambilan keputusan, jika hasil evaluasi buruk maka akan berdampak pada penilaian kerja terhadap Pengguna Anggaran di Kantor DPRD Provinsi Sumbar yang buruk 
pula, sehingga anggaran yang telah ditetapkan menjadi tidak tepat sasaran.Data keuangan yang akan di input kedalam aplikasi tersebut diberikan oleh Pengguna Anggaran (PA), lalu PA di bantu oleh Pejabat Pelaksana Teknis Kegiatan (PPTK). Di kantor DPRD Provinsi Sumbar yang memiliki jabatan sebagai PA yaitu Sekertaris Dewan (Sekwan), dan pembantu PA yang disebut sebagai PPTK di Kantor DPRD Provinsi Sumatera Barat ada 3 bagian yaitu Bagian Umum, Bagian Persidangan dan Bagian Keuangan.

Dengan Aplikasi SIMBANGDA tersebut, pemerintah menargetkan untuk bisa mendapatkan informasi kinerja anggaran dan program instansi pemerintah secara cepat, tepat, dan akurat sebagai bahan pengambilan keputusan sesuai dengan kondisi yang ada serta sebagai input penetapan kebijakan yang relevan. Oleh karena itu data yang di entrikan kedalam aplikasi tersebut harus bersifat akurat dan falid.Berdasarkan latar belakang di atas dapat penulis simpulkan bahwa apliakasi SIMBANGDA tersebut masih terdapat beberapa kekurangan, perhitungan realisasi keuangan di apliaksi tidak sesuai dengan realisasi kenyataaan yang ada, masih kurangnya sosialisasi dari organisasi pengelola aplikasi SIMBANGDA yaitu BKPR dengan DPRD Provinsi Sumbar, dalam proses mengentri data ke aplikasi tersebut pun masih ada kendala yan dirasakan oleh operator yang bertugas menggunakannya, Operator dan PPTK sama-sama merasa bukan tugasnya merubah bukti pengeluaran yang sebelumnya berbentuh hardcopy menjadi softcopy, dan belum adanya standar operasional prosedur yang jelas terhadap penggunaan aplikasi ini. Maka dapat diketahui rumusan masalah pada penelitian ini yaitu :

1. Bagaimanakah efektivitas penerapan aplikasi SIMBANGDA pada Bagian Keuangan di Kantor DPRD Provinsi Sumatera Barat ?

2. Apa saja yang menjadi kendala dalam penggunaan aplikasi SIMBANGDA?

Oleh karena itu penulis tertarik untuk mengetahui bagaimana pengelolaan aplikasi SIMBANGDA dan efektivitas penggunaannya, dengan judul penelitian "Efektivitas Penerapan Aplikasi Sistem Informasi Pembangunan Daerah (SIMBANGDA) Pada Bagian Keuangan di Kantor DPRD Provinsi Sumatera Barat".

\section{Kajian Kepustakaan}

\section{Efektivitas dan Ukuran Efektivitas}

Istilah kata efektif berasal dari bahasa inggris yaitu effective yang berarti berhasil, atau sesuatu yang dilakukan berhasil dengan baik. Keberhasilan organisasi pada umumnya diukur dengan konsep efektivitas, apa yang dimaksud efektivitas, terdapat perbedaan pendapat diantara yang menggunakannya, baik di kalangan akademisi maupun di kalangan praktisi. Sondang P. Siagian(dalam Nora Eka Putri,2014) mendefinisikan efektivitas sebagai keberhasilan penerapan sasaran yang telah ditetapkan. Ini artinya jika hasil kegiatan semakin mendekati sasaran, berarti makin tinggi efektivitasnya. Menurut Effendy dalam Edy Susena (2016) menyatakan Efektivitas berasal dari kata efektif yang mengandung pengertian dicapainya keberhasilan dalam mencapai tujuan yang telah ditetapkan. Sedangkan menurut Steers dalam Edy Sutrisno (2011) mengatakan bahwa yang terbaik dalam meneliti efektivitas ialah memerhatikan secara serempak tiga buah konsep yang saling berkaitan yaitu Optimalisasi tujuan, Perspektif 


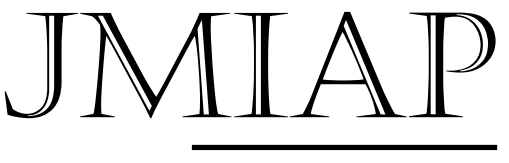

jmiap.ppj.unp.ac.id
Sistem dan tekanan pada segi perilaku manusia dalam susunan organisasi.

Berdasarkan beberapa definisi dari para ahli di atas dapat dipahami bahwa Efektivitas merupakan suatu gambaran untuk melihat seberapa jauh target tercapai dengan melihat usaha serta tujuan yang sudah ditetapkan sebelumnya.Untuk mengetahui efektivitas organisasi dalam melakukan tugas dan mencapai tujuan dapat diketahui melalui beberapa model atau pendekatan efektivitas organisasi.

Sementara itu, menurut Duncan dalam Reza Silvianis (2015) ukuran efektivitas dapat dilihat berdasarkan 1 . pencapaian tujuan, yaitu keseluruhan upaya pencapaian tujuan harus dipandang sebagai suatu proses. Oleh karena itu, agar pencapaian tujuan akhir semakin terjamin, diperlukan pentahapan, baik dalam arti pentahapan pencapaian bagian-bagiannya maupun pentahapan dalam arti periodisasinya. 2. Adaptasi yaitu kemampuan individu atau organisasi untuk menyesuaikan dirinya terhadap lingkungannya 3 . integrasi yaitu kemampuan suatu organisasi dalam melakukan sosialisasi,

Menurut pendapat Cambell yang dikutip oleh Richard M. Steers (1985) dalam bukunya “ Efektivitas Organisasi " menyebutkan beberapa ukuran daripada efektivitas, yaitu:

1. Kualitas artinya kualitas yang dihasilkan oleh organisasi;

2. Produktivitas artinya kuantitas dari jasa yang dihasilkan;

3. Kesiagaan yaitu penilaian menyeluruh sehubungan dengan kemungkinan dalam hal penyelesaian suatu tugas khusus dengan baik;

4. Efisiensi merupakan perbandingan beberapa aspek prestasi terhadap biaya untuk menghasilkan prestasi tersebut;
5. Penghasilan yaitu jumlah sumber daya yang masih tersisa setelah semua biaya dan kewajiban dipenuhi;

6. Pertumbuhan adalah suatu perbandingan mengenai eksistensi sekarang dan masa lalunya;

7. Stabilitas yaitu pemeliharaan struktur, fungsi dan sumber daya sepanjang waktu

8. Kecelakaan yaitu frekuensi dalam hal perbaikan yang berakibat pada kerugian waktu

9. Semangat Kerja yaitu adanya perasaan terikat dalam hal pencapaian tujuan, yang melibatkan usaha tambahan, kebersamaan tujuan dan perasaan memiliki;

10. Motivasi artinya adanya kekuatan yang mucul dari setiap individu untuk mencapai tujuan;

11. Kepaduan yaitu fakta bahwa para anggota organisasi saling menyukai satu sama lain, artinya bekerja sama dengan baik, berkomunikasi dan mengkoordinasikan;

12. Keluwesan Adaptasi artinya adanya suatu rangsangan baru untuk mengubah prosedur standar operasinya, yang bertujuan untuk mencegah keterbekuan terhadap rangsangan lingkungan.

\section{Sistem Informasi Manajemen dan Electronic Government}

Bank Dunia World Bank dalam indrajit (2006) mendefenisikan egovernment sebagai "E-Government refers to the use by government agencies of information thecnologies ( such as Wide Area Network, the internet, and mobile computing) that have the ability to transform relations with citizen, businesses and other arms of government. Yang artinya egovernment merupakan penggunaan teknologi informasi oleh pemerintah seperti Wide Area Network, internet 


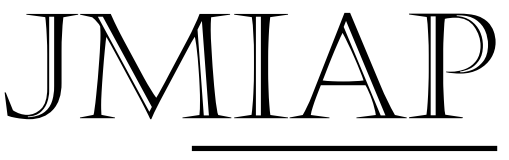

jmiap.ppj.unp.ac.id dan computer mobile yang mempunyai kemampuan mentransformasikan hubungan dengan rakyat rakyat, kelompok bisnis dan aparatur pemerintah".

Menurut Raymond (2008) Sistem Informasi Manajemen adalah suatu sistem berbasis computer yang membuat informasi tersedia bagi para pengguna yang memiliki kebutuhan serupa. Menurut Takalamingan Aldrin (2013) sistem informasi manajemen dibuat sebagai usaha peningkatan fungsi manajemen dengan memanfaatkan bantuan komputer. Sistem informasi manajemen merupakan suatu sistem penghasil informasi berdasarkan komputer yang mendukung sekelompok manajer yang mewakili suatu unit organisasi seperti suatu tingkat manajemen atau suatu bidang fungsional.

Penerapan sistem informasi manajemen dalam lingkungan pemerintahan dikenal dengan istilah Elektronik Government. Menurut Formana (dalam Arifandi, 2009) EGovernment secara umum dapat diartikan sebagai penggunaan sistem teknologi informasi untuk mentransformasikan kegiatan-kegiatan pemerintahan yang bertujuan untuk meningkatkan efektivitas, efisiensi, dan penyampaian layanan. Dengan diterapkannya sistem pemerintahan elektronik (E-Government) dalam penyelenggaraan pemerintahan diharapkan dapat meningkatkan efektivitas serta produktivitas kerja organisasi pemerintahan. Informasi dan data yang didapatkan dari berbagai sumber akan diolah dengan teknologi sistem informasi sehingga nanti akan didapatkan data yang kompleks yang dapat digunakan oleh organisasi dalam pengambilan keputusan.

Sistem Informasi Pembangunan Daerah (SIMBANGDA) merupakan salah satu aplikasi sistem informasi yang juga merupakan salah satu produk dari penerapan prinsip Elektronik Government. Dengan diterapkannya aplikasi SIMBANGDA ini berarti pemerintah sudah menerapkan elektronik government sebagai sebuah sistem informasi. Apabila dilihat dari asal katanya electronic government terdiri dari dua kata yaitu "elctronic" dan "government" yang apabila diartikan ke dalam bahasa Indonesia menjadi pemerintah elektronik. Jika diartikan dari asal katanya jadi elektronik government merupakan penggunaan teknologi informasi dalam penyelenggaraan pemerintahan.

Dari beberapa defenisi diatas, dapat disimpulkan defenisi E-Government menurut Pemerintah Republik Indonesia, sebagaimana diatur oleh Kementerian Komunikasi dan Informatika (Keminfo) adalah pelayanan public yang diselenggarakan melalui situs pemerintah dimana domain yang digunakan juga menunjukan domain Pemerintah Indonesia yakni go.id. Sehingga berdasarkan defenisi formal ini, walaupun ada website yang secara real dikelola oleh pemeritah dan digunakan untuk pelayanan public namun tidak berdomain go.id maka tidak termasuk klasifikasi E-Government.(Strategi Pengembangan E-Government dalam Pelaksanaan Diseminasi Informasi Pemerintah Kota Palembang. 2009).

\section{Kendala dalam Penerapan Program}

Cox dan schelier dalam Selviana dan Setya (2016) menyatakanTheory of constraintsatau juga dikenal dengan TOC merupakan sebuah filosofi manajemen yang dikembangkan oleh Dr. Eliyahu M. Goldratt sejak tahun 1980-an. Theory of constraints didefinisikan sebagai suatu pendekatan 
ke arah peningkatan proses yang berfokus pada elemen-elemen yang membatasi kinerja dalam peningkatan output.

Hansen dan Mowen dalam Selviana dan Setya (2016) mengelompokkanjenis kendala berdasarkan asalnya dan berdasarkan sifatnya.

1) Berdasarkan Asalnya:

a) Kendala Internal (Internal constraint) adalah faktor-faktor yang membatasi perusahaan ataupun organisasi dan sistem yang berasal dari dalam perusahaan.

b) Kendala Internal (Eksternal constraint) adalah faktor-faktor yang membatasi perusahaan yang berasal dari luar perusahaan. Atau dapat diartikan berasal dari luar organisasi ataupun sebuah sistem.

2) Berdasarkan sifatnya:

a) Kendala mengikat (binding constraint) adalah kendala yang terdapat pada sumber daya yang telah dimanfaatkan sepenuhnya.

b) Kendala tidak mengikat atau kendur (loose constraint) adalah kendala yang terdapat pada sumber daya yang terbatas yang tidak dimanfaatkan sepenuhnya.

\section{Sistem Informasi Pembangunan Daerah (SIMBANGDA)}

Sistem Imformasi Pembangunan Daerah (SIMBANGDA) yaitu aplikasi yang digunakan untuk membantu pelaksanaan pengendalian program, kegiatan, penyerapan anggaran, dan penyusunan laporan serta penerapan egovernment di daerah. Penerapan Aplikasi Simbangda berdasarkan instruksi presiden republik indonesia nomor 3 tahun 2003 tentang strategi dan kebijakan nasional pengembanganegovernment. Sistem Informasi Pembangunan Daerah diatur dalam Undang-Undang Nomor 32
Tahun 2004 tentang Pemerintahan Daerah yang kemudian direvisi menjadi Undang-Undang Nomor 23 Tahun 2014 pada pasal 274 mengamanatkan bahwa perencanaan pembangunan daerah didasarkan pada data dan informasi yang dikelola dalam Sistem Informasi Pembangunan Daerah. Hal ini semakin memperkuat posisi Sistem Informasi Pembangunan Daerah sebagai bahan rujukan dalam proses penyusunan dokumen perencanaan pembangunan daerah. Namun penggunaan aplikasi SIMBANGDA sebagai acuan dalam penyusunan dokumen perencanaan pembangunan daerah difokuskan kepada pemanfaatan informasi yang dihasilkan berdasarkan pengolahan data yang telah diinput oleh pemerintah daerah.

Gambaran umum pemakaian aplikasi SIMBANGDA adalah sebagai berikut :

1. Bagian/Sub Bagian Program pada masing-masing SKPD

Pemakai (User) ini bertugas memasukkan data kegiatan, anggaran, target realisasi diawal tahun, serta realisasi setiap bulannya baik fisik maupun keuangan.

2. PA/KPA pada masing-masing SKPD

Pemakai (User) ini dapat melihat informasi realisasi pelaksanaan kegiatan pada SKPD mereka guna pengendalian kegiatan dilingkungan SKPD mereka. Pengguna Anggaran (PA)

3. Bagian/Sub Bagian pada Biro Administrasi Pembangunan dan Kerjasama Rantau/Bagian Pembangunan pada Kab/Kota Pemakai (User) ini dapat melihat informasi realisasi pelaksanaan kegiatan pada SKPD mereka guna kebutuhan penyiapan bahan rapat monev bersama Gubernur, pengendalian kegiatan pembangunan, pelaporan dan lain-lain. 


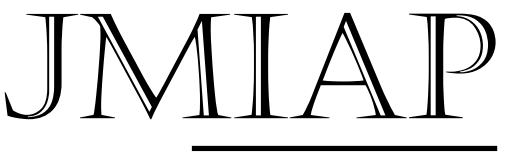

jmiap.ppj.unp.ac.id
4. Pengelola Simbangda (User Admistrator)

Pemakai (User) ini bertugas melakukan pengaturan terhadap siapa yang berhak mengakses dan sejauh mana haknya dengan memberikan nama user (user name) dan kata kunci masuk (password), serta melakukan pengelolaan dan perawatan. Setiap user akan memperoleh nama user (user name) dan kata kunci masuk (password) untuk dapat menggunakan Aplikasi Program Simbangda tersebut. Untuk efisiensi penggunaan SDM, maka user pada SKPD dapat diwakilkan ke petugas/operator pada Bagian/Subag program.

\section{Metode Penelitian}

Penelitian ini merupakan penelitian kualitatif dengan metode deskriptif. Informan penelitian ditentukan secara purposive.Informan penelitian disini yaitu opearator SIMBANGDA pada bagian keuangan di Kantor DPRD Provinsi Sumbar serta organisasi yang bertugas mengelola aplikasi tersebut yaitu Biro Kerjasama Pembangunan dan Rantau.

Teknik pengumpulan data dilakukan dengan cara observasi, wawancara dan studi dokumentasi.Uji keabsahan data dilakukan dengan teknik triangulasi sumber. Selanjutnya analisis data dilakkan dengan langkahlangkah: reduksi data, display data, dan penarikan kesimpulan dari hasil penelitian.

\section{Pembahasan}

1. Efektivitas Penerapan Aplikasi SIMBANGDA pada Bagian Keuangan di Kantor DPRD Provinsi Sumbar

Menurut Effendy dalam Edy Susena (2016) menyatakan Efektivitas berasal dari kata efektif yang mengandung pengertian dicapainya keberhasilan dalam mencapai tujuan yang telah ditetapkan. Sebagaimana diketahui penerapan suatu sistem dari sebuah kebijakan harus diihat seberapa efektif sistem itu dilaksanakan dengan melihat pencapaian tujuan dari sistem tersebut. Efektiviats penerapan Aplikasi SIMBANGDA berarti melihat seberapa efektif penerapan sistem tersebut dalam pencapaian tujuannya, serta bagaimana proses yang dilaksanakan dalam penerapannya.

Tingkat keefektivan suatu program umumnya diukur dengan seberapa jauh target (kualitas, kuantitas, dan waktu) yang telah tercapai. Mengetahui tingkat keefektifan suatu program merupakan hal yang sangat perlu dilakukan untuk kepentingan suatu organisasi. Tingkat efektivitas penerapan SIMBANGDA pada bagian keungan di Kantor DPRD Provinsi Sumatera Barat dapat diukur dengan menggunakan beberapa indikator pengukuran efektivitas yang dikemukakan oleh Duncan yaitu dengan melihat sejauh mana pencapaian tujuan telah terlaksana , integrasi atau sosialisasi terhadap Aplikasi ini serta bagaiman proses adaptasi individu atau penyesuain diri terhadap Aplikasi ini. Serta untuk memperkuat data mengenai efektivitas penerapan aplikasi SIMBANGDA penulis juga melakukan penelitian di Kantor Biro Kerjasama Pembangunan dan Rantau .

Analisa Efektivitas penerapan Aplikasi SIMBANGDA dapat dilihat dengan beberapa indikator yaitu, (a) Pencapaian Tujuan, (b) Integrasi, dan (c) Adaptasi.

\section{a. Pencapaian Tujuan}

Keselurhan upaya pencapaian tujuan harus dipandang sebagai suatu proses. Oleh sebab itu, supaya pencapaian tujuan akhir semakin terjamin, diperlukan pentahapan, baik 


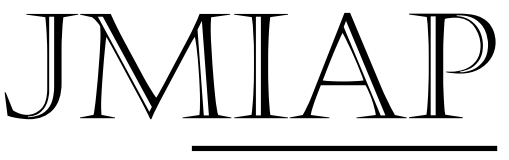

jmiap.ppj.unp.ac.id dalam arti pentahapan pencapaian bagian-bagiannya maupun pentahapan dalam arti periodisasinya. Pencapaian tujuan terdiri dari beberapa faktor, yaitu: Kurun waktu dan sasaran yang merupakan target kongkret. Pencapaian tujuan dalam penerapan Aplikasi SIMBANGDA pada Bagian Keuangan di Kantor DPRD Provinsi Sumatera Barat berjalan dengan cukup baik. Namun, masih banyak persoalanpersoalan dalam pencapaian tujuan yang harus diperbaiki untuk ke depan. Hal utama yang menjadi perbaikan adalah sistem yang ada pada Aplikasi ini harus segera dievaluasi agar tidak terjadi kesalahan-kesalahan dalam perhitungan realisasi keungan yang dapat merugikan pihak terkait. Seperti hasil wawancara yang telah peneliti laukakan kepada operator SIMBANGDA di Bgaian Keuangan Knator DPRD Provinsi Sumatera Barat beliau mengatakan:

"....memang ada kesalahan perhitungan realisasi keungan pada Aplikasi tersebut, seperti pada tahun ini, disaat realiasai baru berjalan $50 \%$ tetap perhitungan di aplikasi sudah mencapai $67 \%$ sehingga yang ditakutkan sebelum akhir tahun nanti realisasi yang seharusnya baru 90\% tetapi sudah mencapai $100 \% "$

Dari hasil wawancara tersebut dapat diketahui untuk aplikasi SIMBANGDA sendiri masih terdapat kekurangan seperti perhitungan realisasi keungan didalmnya tidak sesuai dengan kenyataan yang ada, hal tersebut dapat merugikan instansi terkait dan proses pengambilan keputusan dalam perencanaan pembangunan nantinya menjadi tidak tepat sasaran.

Dalam Undang-Undang Nomor 23 Tahun 2014 tentang Pemerintah Derah pada pasal 274 mengamanatkan bahwa "perencanaan pembangunan daerah didasarkan pada data dan informasi yang dikelola dalam Sistem Informasi Pembangunan Daerah". Hal ini semakin memperkuat posisi Sistem Informasi Pembangunan Daerah sebagai bahan rujukan dalam proses penyusunan dokumen perencanaan pembangunan daerah, tetapi jika data dan informasi yang ada pada Aplikasi SIMBANGDA ini tidak sesuai dengan kenyataan yang ada maka proses pengambilan keputusan dalam perencanaan pembangunan nantinya menjadi tidak tepat sasaran. Kesalahan perhitungan realisasi keungan pada Aplikasi ini sebenarnya dapat diatasi dengan membuat rumus penyeimbang didalamnya, namun dari hasil wawancara yang peneliti lakukan dengan operator SIMBANGDA pada Bagian Keuangan di Kantor DPRD Provinsi Sumatera Barat beliau mengatakan pihak Biro Kerjasama Pembangunan dan Rantau kurang tanggap terhadap keluhan mereka yang tentu saja nantinya dapat merugikan mereka, pihak BKPR hanya berjanji akan mengevaluasi Aplikasi tetap hingga saat ini belum ada perubahan pada aplikasi ini.

Lebih penulis mewawancarai Pejabat Pelaksana Teknis Kegiatan (PPTK) pada Bagian Umum yang bertugas memberikan data tentang pengadaan barang dan jasa pada operator SIMBANGDA, beliau mengatakan :

“...Kami sebagai PPTK bertugas memberikan data tentang proses pengadaan barang dan jasa pada bagian keungan atau operator SIMBANGDA, menurut saya Aplikasi ini sebenarnya sangat membantu dalam melaporkan hal-hal yang berhubungan dengan realisasi fisik atau keungan, hanya saja dengan adanya perubahan sistem yaitu setiap bukti fisik seperti foto-foto, kwitansi harus di entrikan ke dalam 


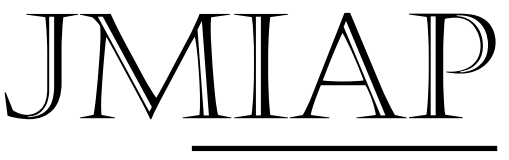

jmiap.ppj.unp.ac.id sistem, sehingga terjadi ketidakjelasan dalam pembagian tugas, karena yang terjadi operator meminta saya yang merubah segala bukti yang beerbentuk hardcopy menjadi softcopy"

Dari hasil wawancara diatas dapat dilihat bahwa dalam proses pembagian tugas dalam penggunaan Aplikasi SIMBANGDA ini masih belum jelas, karena yang terjadi PPTK masih mengeluhkan tentang tugasnya yang terkadang masih harus merubah bukti-bukti yang berbentuk hardcopy menjadi softcopy.Dalam wawancara yang penulis lakukan kepada pihakpihak terkait, mereka mengatakan bahwa sebenarnya aplikasi ini membantu dalam pelaporan realisasi keungan, karena operator hanya perlu duduk di kantor dan menggunakan fasilitas yang sudah disediakan oleh kantor untuk membut laporannya seperti komputer dan perangkat pendukung lainnya serta jaringan internet yaitu Wifi yang telah terpasang di Kantor DPRD Provinsi Sumatera Barat ini.

\section{b. Integrasi}

Integrasi adalah pengukuran terhadap tingkat kemampuan dan keberhasilan suatu organisasi untuk mengadakan sosialisasi, pengembangan konsensus dan komunikasi dengan berbagai macam organisasi lainnya. Integrasi menyangkut proses sosialisasi. Biro Kerjasama Pembangunan dan Rantau (BKPR) merupakan Organisasi yang bertugas mengelola dan menghimpun data dari setiap SKPD, setiap SKPD wajib mengentrykan data realisasi keungan mereka dan mengirimkannya kepada Biro Kerjasama dan Rantau pada Tanggal 8 setiap bulannya, lalu Biro kerjasama Pembangunan dan Rantau akan melakukan rapat Monev atau Monitoring Evalusi setiap 3 bulan sekali untuk menilai hasil realisasi keungan yang telah terlaksana disetiap SKPD terkait.

Berdasarkan hasil wawancara yang penulis lakukan pada bagian keungan di Kantor DPRD Provinsi Sumbar terlihat bahwa masih kurangnya sosialisasi dari BKPR, berikut kutipan wawancara yang penulis lakukan dengan operator SIMBANGDA di bagian keuangan pada kantor DPRD Provinsi Sumbar

“...Untuk sosialisasi dalam penggunaan apliaksi ini saya rasa masih kurang, tidak ada aturan yang jelas dalam penggunaanya, kami hanya dijelaskan secara lisan saja oleh pihak BKPR, sehingga kami terkadang juga bingung dengan perubahan yang terjadi, seperti dilakukannya perubahan sistem baru, yang mengharuskan setiap SKPD mengentrikan apapun yang dapat dijadikan bukti fisik dalam realisasi keungan, saya sebagai operator merasa itu tugas PPTK yang harus memberikan data keungan dan bukti fisik tersebut, sedangkan PPTK sendiri merasa itu menjadi bagian dari tugas operator"

Menurut hasil wawancara yang telah peneliti lakukan kepada operator SIMBANGDA pada Bagian Keungan di Kantor DPRD Provinsi Sumatera Barat mereka menyampaikan dalam penggunaan Aplikasi SIMBANGDA ini belum ada aturan-aturan yang jelas dalam proses pengoperasiannya, sosialisasi yang dilakukan oleh Biro Kerjasama Pembangunan dan Rantau pun dirasakan kurang oleh pihak DPRD, dikarenakan pihak BKPR hanya memerintahkan oparator untuk membuat laporan realisasi keungan menggunakan Aplikasi SIMBANGDA saja, dan menjelaskan sedikit tentang aplikasi ini, tidak ada sosialisasi yang benar-benar membuat operator paham, dan operator tidak diberikan file-file petunjuk dalam penggunaanya seperti power point ata buku-buku petunjuk. 


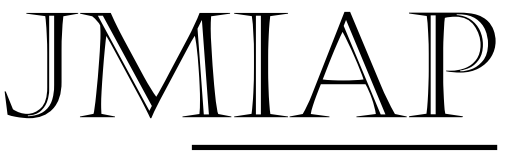

jmiap.ppj.unp.ac.id
Email : jianfis.unp@gmail.com Vol. 1 No. 1 Tahun 2018
Peneliti juga melakukan wawancara dengan Kepala Biro Kerjasama Pembangunan dan Rantau, dari hasil wawancara tersebut dapat diketahui bahwa memang belum ada Standar Operasional Prosedur dalam Penggunaan Aplikasi SIMBANGDA ini, tetapi pihak Biro Kerjasama Pembangunan dan Rantau mengatakan telah melakukan komunikasi secara lisan dengan SKPD terkait termasuk pada Bagian Keungan di Kantor DPRD Provinsi Sumtera Barat.

\section{c. Adaptasi}

Adaptasi merupakan kemampuan organisasi untuk menyesuaikan diri dengan lingkungannya. Hal ini bisa dilihat dengan bagaimana Operator SIMBANGDA mampu beradaptasi dengan lingkungan kerja dan mampu menjalankan tugas dengan menyesuaikan diri dengan keadaan di lapangan. Dalam proses entri data kedalam Aplikasi SIMBANGDA ini ditugaskan kepada Staff Akuntansi Pelaporan dan Verifikasi.

Apliksi

SIMBANGDA menciptakan beberapa perubahan yang terjadi dan dirasakan pada bagian keungan di Kantor DPRD Provinsi Sumbar. Perubahan tersebut seperti operator harus tepat waktu dan teliti dalam melaporkan dan mengentri data keungan kedalam aplikasi tersebut, karena jika ada data yang salah operator harus melaporkannya kepada Biro Kerjasama Pembangunan dan Rantau sebagai instansi yang mengelola Apliaksi SIMBNGDA untuk membukakan sistem dan memperbarui data yang salah tersebut. Perubahan lainnya yaitu dengan adanya perubahan sistem yang mengharuskan setiap OPD mengentrikan segala bukti fisik ke dalam aplikasi tersebut menjadikan operator dan pengguna anggaran merasa bahwa perubahan itu bukan tanggung jawabnya. Dengan adanya

perubahan-perubahan tersebut staff bagian keungan harus bisa bersosialisasi agar dapat terus berkembang semakin maju.

Dari hasil wawancara yang penulis lakukan dapat dilihat bahwa operator yang ditugaskan untuk menjadi Operator SIMBANGDA ada 3 orang, tetapi tidak semua operator yang ditugaskan dapat mengoperasikan SIMBANGDA dikarenakan kemampuannya terhadap teknologi informasi yang masih kurang, dapat penulis simpulkan tidak semua Sumber Daya Manusia yang ada di Kantor DPRD Provinsi Sumatera Barat dapat beradaptasi dengan perubahanperubahan yang terjadi dilingkungannya.

Ada beberapa perubahan sistem pada Aplikasi SIMBANGDA yaitu setiap SKPD wajib mengentrikan apapun yang menyangkut bukti realisasi keungan seperti kwitansi, fotofoto dan apapun yang berhubungan dengan bukti fisik dan pengeluaran ke dalam apliakasi tersebut, dengan menjadikannya softcopy agar dapat di upload kedalam aplikasi SIMBANGDA. Dengan adanya perubahan tersebut operator dan Pejabat Pelaksana Teknis Kegiatan (PPTK) sama-sama merasa itu bukan tugasnya. Masalah lainnya yaitu OPD masih belum terbiasa dan menganggap hal itu hanya menambah pekerjaan saja, tetapi karena itu merupakan tugas wajib mau tidak mau tetap harus dikerjakan.

$\begin{array}{ccr}\begin{array}{c}\text { Penulis } \\ \text { juga }\end{array} & \text { melakukan } \\ \text { wawancara } & \text { dengan } & \text { oprator }\end{array}$
SIMBANGDA pada bagian Keuangan di Kantor Bappeda Provinsi Sumbar beliau mengatakan,

“...Untuk adaptasi menurut saya masih banyak staff yang menganggap dengan adanya sistem baru pada aplikasi SIMBANGDA ini hanya menambah pekerjaan saja, tetapi karena ini 


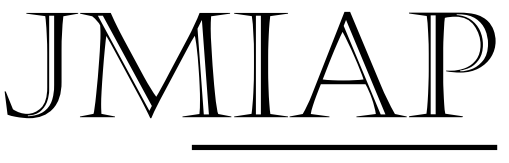

jmiap.ppj.unp.ac.id merupakan tugas wajib dan akan di monitoring dan evaluasi oleh Gubernur maka mau tidak mau tetap harus dilakukan"

Berdasarkan hasil wawancara diatas dapat penulis simpulkan bahwa OPD belum dapat beradaptasi dan melakukan peneysuaian dengan perubahan yang ada, sehingga masih terdapat unsur keterpaksaan dalam melakukan tugasnya.

\section{Faktor yang menjadi kendala dalam Penerapan Aplikasi SIMBANGDA pada Bagian Keungan di Kantor DPRD Provisni Sumbar}

Penerapan aplikasi SIMBANGDA dalam proses pelaporan keuangan di Kantor DPRD Provinsi Sumatera Barat masih mengalami kendala demi terwujudnya keefektifan dalam penggunaannya. Ada 2 kendala yang diungkapkan Hansen dan Mowen dalam Selviana dan Setya (2016) bahwa jenis kendala dapat dikelompokkan berdasarkan asal menjadi dua macam, yaitu: Gangguan dalam penerapan sistem informasi dapat dikelompokan kedalam dua hal yaitu kesalahan teknis yang terjadi akibat kesalahan perangkat keras, kesalahan dalam program aplikasi perangkat lunaknya, kelalaian manusia yang tidak disengaja termasuk juga gangguan lingkungan karena menggunakan data yang salah, serta penghapusan data tanpa disengaja.

Kendalam dalam penggunaan Apliaksi ini disampaikan oleh opeatror SIMBANGDA beliau mengatakan.

"...Di saat kami sedang melakukan proses entri data terkadang Aplikasinya sering keluar sendiri dan muncul dialog mercusuar, sehingga data yang suadah kami entrikan sebelumnya harus kami masukan ulang kembali, dan itu membuat pekerjaan kami menjadi semakin lama"
Dalam penggunaan Aplikasi SIMBANGDA ini yaitu saat operator melakukan proses entry data aplikasi sering eror dan keluar sendiri lalu keluar tulisan mercusuar sehingga data yang sudah dienrtykan sebelumnya harus diulang memasukannya.

Proses pengelolaan keuangan menggunakan aplikasi SIMBANGDA di Bagian Keungan pada Kantor DPRD Provinsi Sumbar fungsinya belum optimal sebagaimana yang diharapkan. Adapun faktor yang menghambat antara lain kelalaian manusia dalam proses entri data ke Aplikasi SIMBANGDA, akibatnya operator harus menghubungi Biro Kerjasama Pembangunan dan Rantau untuk mebukakan sistem agar bisa merubah data yang salah .Selain itu ketersediaan pengguna yang menguasai SIMBANGDA juga menjadi penghambat penerapan SIMBANGDA di bagian keungan, sehingga hanya 2 orang Operator saja yang saling bekerjasama untuk membuat laporan realisasi keungan menggunakan Aplikasi ini. Berikit ini hasil wawancara yang penulis lakukan dengan operator SIMBANGDA pada bagian keuangan di Kantor DPRD Provinsi Sumbar .

“...Untuk keterlambatan dalam mengirimkan data Bagian Keungan di Kantor DPRD Provinsi Sumatera Barat tidak pernah terlambat, hanya saja sesekali ada kesalahan dalam datanya dan mereka menghubungi kami untuk dibukakan sistemnya kembali agar mereka bisa memperbaiki datanya"

Dari wawancara diatas terlihat bahwa kesalahan umumnya berasal akibat kelalaian pengguna. Kesalahan dalam menginput data saja dapat menimbulkan berbagai masalah seperti tidak bisa mencairkan dana, data yang berubah akibat salah input data, selain itu kalalaian dalam menginput data 
realisasi yang mempengaruhi data laporan akhir tahun.

\section{Kesimpulan dan Saran}

Dari hasil penelitian dan pembahasan yang dilakukan, maka penulis mengambil kesmpulan sebagai berikut.

1. Program Aplikasi SIMBANGDA sudah berhasil di terapkan pada Bagian Keungan di KantorDPRD. Dengan diterapkannya SIMBABGDA di Bagian Keungan dapat mengelola keuangannya dengan mudah tanpa melakukan pencatatan secara manual. Kesimpulan pada penelitian ini terdiri atas 3 indikator. (1) Secara keseluruhan aplikasi ini membantu pelaporan hasil realisasi keungan. Tetapi dengan adanya kesalahan perhitungan realisasi keungan di dalam aplikasi tersebut sehingga tujuan pada aplikasi ini menjadi tidak tepat sasaran, (2) Integrasi atau Sosialiasi yang dilakukan oleh pihak pengelola dirasakan juga masih kurang oleh operator SIMBANGDA pada Bagian Keungan di Kantor DPRD Provinsi Sumatera Barat, (3) serta adaptasi dari operator SIMBANGDA sendiri masih belum maksimal karena masih ada yang belum memahami cara menggunakan SIMBANGDA

Apliaksi

2. Beberapa faktor yang mendukung efektivitas penerapan SIMBANGDA pada Bagian Keungan di Kantor DPRD Provinsi Sumatera Barat antara lain ketersedian perangkat keras dan perangkat lunak yang sudah cukup memadai. Namun dari segi pengguna, operator SIMBANGDA yang seharusnya mengerti dalam penggunaannya masih ada yang belum bisa mengoperasikan
SIMBANGDA karena kurang bisa beradaptasi dengan semakin majunya teknologi informasi, dan masih terdapat anggapan dari OPD bahwa dengan adanya aplikasi ini hanya menambah pekerjaan saja.

Berdasarkan hasil penelitian yang telah dilakukan dilapangan, maka penulis memberikan beberapa rekomendasi saran demi meningkatkan efektivitas penerapan aplikasi SIMBANGDA pada Keungan di Kantor DPRD Provinsi Sumatera Barat, beberapa rekomendasi saran tersebut antara lain:

1. Diharapkan Aplikasi ini segera dievaluasi agar tidak terjadi kesalahan perhitungan realisasi keungan secara terus menerus yang dapat menyebabkan proses pengambilan keputusan dalam perencanaan pembangunan menjadi tidak tepat sasaran sehingga penerapan Aplikasi SIMBANGDA ini dapat lebih evektif lagi.

2. Upaya yang dapat dilakukan dalam mengefektivkan penerapan Aplikasi SIMBANGDA pada Bagian Keungan di Kantor DPRD Provinsi Sumatera Barat antara lain: a) dengan menyediakan sarana dan prasarana dalam pengoperasian SIMBANGDA, seperti komputer dan jaringan internet yang baik b) merencanakan serta mengusulkan penambahan jumlah operator SIMBANGDA pada Bagian Keungan c) harus adanya pembagian tugas yang jelas agar operator dan PPTK tidak saling melimpahkan wewenang dalam menyelesaikan tugasnya. d) Perlu dilakukannya sosialisasi oleh Biro Kerjasama dan Rantau agar operator SIMBANGDA disetiap 
SKPD tidak ada yang sering melakukan kesalahan.

3. Diharapkan bagian Keungan di Kantor DPRD Provinsi Sumbar agar dapat lebih meningkatkan kualitas Sumber Daya Manusia sehingga dapat menjalankan tanggung jawab yang telah diberikan secara lebih baik lagi.

\section{DAFTAR KEPUSTAKAAN}

Edy Susena, S.Kom, M.Kom, Dewi Amelia Lestari, S.Kom, MM. 2016.Efektivitas Penerapan Electronik Government Terhadap Pelayanan Publik di Kabupaten Sragen.Jurnal Vol. 2, No. 6.

Indrajit, Richardius Eko. 2006. Elektronik Government. Yogyakarta

Edy Sutrisno. 2011. Budaya organisasi. Jakarta: Kencana Prenada Media Group.

Lexy J. Moeloeng. 2006. Metode Penelitian Kualitatif. Bandung: PT Remaja Rosdakarya.

Nora EkaPutri. 2014. Efektivitas penerapan jaminan kesehatan nasional melalui bpjs dalam pelayanan kesehatan masyarakat miskin di kota padang.JurnalVol. 10, No. 2

Raymond Mcleod. 2008. Sistem informasi manajemen. Jakarta: Salemba Empat.

Reza Silvianis. 2015. Efektivitas Organisasi dalam Pelaksanaan Pembangunan Infrastruktur Di Desa Sotol Kecamatan Langgam Kabupaten Pelalawan Tahun 2011-2013.Jurnal Vol. 2, No. 1.

Selviana Putri Larasati, Setya Haksama. 2016. Penerapan Theory of Constraint Pada Kepuasan Kerja Karyawan Rumah Sakit Mata Undaan Surabaya. Jurnal Vol 4, no. 2. Tahun 2016.

Takalamingan Aldrin. 2013. Media Engineering. Sistem Informasi Manajemen Pengendalian Persediaan Bahan Instalasi Perpipaan pada Satuan Kerja Pengembangan Kinerja
Pengelolaan Air Minum.Jurnal Ilmiah Vol. 3 , No. 2.

Undang-Undang No 23 Tahun 2014 tentang Pemerintahan Daerah 
